\title{
The democratization of Russian
}

\section{Mustajoki, Arto}

Routledge

2019

Mustajoki , A 2019 , The democratization of Russian . in A Mustajoki , E Protassova \& M Yelenevskaya (eds), The soft power of the Russian language : Pluricentricity, politics and policies . Studies in Contemporary Russia , Routledge , Abingdon , pp. 21-34 . https://doi.org/10.4324/97804290611

http://hdl.handle.net/10138/323518

https://doi.org/10.4324/9780429061110-3

acceptedVersion

Downloaded from Helda, University of Helsinki institutional repository.

This is an electronic reprint of the original article.

This reprint may differ from the original in pagination and typographic detail.

Please cite the original version. 


\section{The Soft Power of the Russian Language: Pluricentricity, Politics and Policies}

Arto Mustajoki, Ekaterina Protassova, Maria Yelenevskaya (eds.)

Abingdon

Routledge 2019 


\section{DEMOCRATIZATION OF THE RUSSIAN LANGUAGE}

\section{Arto Mustajoki}

On the Russian question-and-answer website Otvety@mail.ru, a seven-year-old girl asked what was meant by the democratization of language (demokratizatsiia jazyka). She received, among others, the following answers: "Read how they write questions: lots of mistakes. This is democratization of language!", "Perhaps freedom of speech (svoboda slova)". This is one aspect in approaching the question of the democratic nature of language, but not the only one. The purpose of this paper is to consider the topic from a wider perspective.

People are not born with equal opportunities. This also concerns their linguistic capabilities. At the same time, human language is, by its very nature, democratic in the sense that all children learn their mother tongue in a similar way-by imitating the speech of their parents and building on that basis their own personal grammars and vocabularies, which gradually start to resemble the 'correct' language of the people around them.

Language is also democratic in terms of communication. Interaction between people is possible only if they speak in a relatively similar manner. In natural circumstances, linguistic norms are created by the language communities themselves without any pressure from above. Languages without a literary tradition, and slangs or dialects of any language, are constructed in this way: speakers are their creators. This joint ownership of a language (or a language variety) guarantees mutual understanding. The need to be understood is reflected in the scale of differences between dialects: neighboring dialects differ from each other but only slightly, while speakers of dialects separated geographically may not be able to understand each other.

The feeling they speak the same language is important for the cohesion and identity of communities, although Boris Gasparov (2014) points out that belongingness to a certain language group $^{1}$ is to a large extent based on false impressions. Members of a group feel that they speak in a similar way, although differences between them are often substantial. What is important here is the feeling of being part of a homogeneous entity.

In the case of a dialect or slang, it is clear that they are owned by their users who determine how to speak. The term 'collective norm' can be used with reference to such forms of language. ${ }^{2}$ The norm is not stable, and what is relevant is the nature of the process: the stimulus for possible changes comes from the group itself. In that sense, such language varieties are the result of unconscious joint efforts by their speakers. ${ }^{3}$

In an organized society linguistic norms are established on a "top down" basis by the authorities. In fact, a modern state badly needs its own language with a codified linguistic norm. I call it 'official norm'. It is maintained in prescriptive dictionaries and grammars and taught in schools. The need to have a common standard language is a relatively new phenomenon in history and can be linked to the idea of a nation-state (see Taylor 1990; Gal, Irvine 1995). The identitybuilding role of a nation's own 'titular' language is not a simple issue. One interesting aspect is the multiethnic and multilingual nature of a country, cf. Suleimenova (2010a) on the role of language in building national identity. A curious opposite example in this respect is Moldova, which has decided to rename its language from Moldavian to Romanian.

The official norm is not the result of a natural process of language development, but an artefact produced by people or organizations that have been granted an official status as normmakers. As pointed out by Shcherba (1974/2007: 315) and Zemskaja (1987), the official norm

\footnotetext{
${ }^{1}$ There are also other criteria on which group identities are based, e.g., racial, religious, or ethnic belonging.

${ }^{2}$ For discussion on differences between collective norm and official norm (codification of language), see Mustajoki 2013.

${ }^{3}$ In any group or society there are members who are more influential than others; the language of such people becomes a model to be imitated by the rest of the group.
} 
which is taught at school is, so to speak, a foreign language for the young pupils, and it takes years of hard work to learn it.

The aim of this paper is to consider the ownership question from the perspective of the contemporary Russian language: who has the right to determine the literary norm within Russia and beyond Russia? A related question arises: to what extent is it permissible not to follow the rules set from above. Before going on to consider these issues, we will take a brief look at whether the process of linguistic normalization should be viewed as democratic or antidemocratic.

\section{Ownership of a linguistic norm and its (anti)democratic nature}

Various options are available for determining the official norm of a given language. One is to give this right to some administrative body or institution. Another is to let elites make decisions without seeking official approval. In both cases the situation is the same from the perspective of the vast majority of native speakers: the official norm is imposed from above without giving them an opportunity to influence its acceptance. Such a process looks clearly antidemocratic. A small number of people determine how the majority should use their mother tongue, at least in written contexts. This may be construed as a form of power exertion by 'the strong ones'. However, there is also space for an opposite view. Having a standard language with explicit normative rules makes it possible for everyone to speak correctly. In that sense it is possible to see democratic elements in the existence of an official norm, as it enables lower classes to speak and write in a proper fashion (Coupland, Kristiansen 2011).

The ownership question has another dimension connected to multipolar or pluricentric language development. A glance at the contemporary situation with Englishes clarifies the issue. Kachru (1985) speaks of countries belonging to the inner circle and the outer circle of various Englishes. A more systematic and analytical approach is demonstrated in the huge eWAVE database, where 76 varieties of English are listed (Kortmann, Lunkenheimer 2013). The ownership and the right to determine an official norm has been distributed among various places. In fact, no real transition of ownership rights has taken place, but language communities have simply begun to see their position and rights in that way. The inhabitants and authorities of Kenya or Ghana may follow the norms set by the British or the Americans, but they can also determine local language norms.

Thus, English is a pluricentric language with numerous speech communities using local varieties of the common language. The new situation where English is also an international language used by billions of people everywhere in the world has added a new perspective to the question of a linguistic norm. Who owns that lingua franca, and how are its norms established? This question could be eliminated by saying that we are dealing with a learners' language or an interlanguage that simply represents bad English, reflecting an improper command of the language. In the light of recent research, such a view does not correspond to the real essence of this language variety. English as a lingua franca (ELF) is often used by people who are fluent in English (Dewey 2009). The simplified language they use is primarily a result of their communication strategy, and only secondarily a consequence of deficient language command. ELF is an effective tool of interaction, and communication failures are surprisingly rare in ELF conversations (House 2003; Mauranen 2006; Mustajoki 2011).

Kachru (1985) points out that ELF, unlike native Englishes, is a norm-independent language. It has no homeland and is not described in dictionaries. In that sense, it can be compared to natural language varieties such as dialects and slangs. People using ELF often concentrate on mutual understanding and do not care about the correctness of their language (Firth, Wagner 1997; Hülmbauer 2009). In speaking our native language we often try to follow the norms of the variety concerned (slang, sociolect, or others) in order to show our belongingness to a particular social group. 


\section{Democratic switch in the use of Russian}

With regard to language usage, uniform processes have taken place in all modern societies in the last few decades. Everywhere we witness vernacularization of language: the language seen and heard in everyday life is becoming less formal and closer to the language used in informal situations. This trend is visible in face-to-face interaction as well as in written forms. This phenomenon is particularly evident in the mass media, where features of colloquial speech have substantially increased in contexts that used to require a more formal style. ${ }^{1}$

In Russia, a similar democratization process in language usage has occurred more radically and faster than in other countries (Kon'kov et al. 2004). The Soviet public language, which (typically for a totalitarian country) had been very stiff and regulated, was replaced by an exceptionally multi-voiced linguistic landscape that allowed for almost everyone to be heard in the public space. Krysin (2000) sees the following factors in this process: democratization of Russian society as a whole, de-ideologization of various spheres of human activity, antitotalitarian tendencies, deletion of prohibitions and restrictions in political and social life, and openness to the Western trends in economics, politics, and culture.

Another authoritative view on the twist in language usage has been proposed by Zemskaja (1996), who notes several turning points in the linguistic landscape of Russia: a wider range of participants in mass communication, weakening of censorship and self-censorship, an increasingly personal tone and dialogic nature of speech, and a growing frequency of spontaneous speech in personal and public communication.

The change in language practices in the public sphere evoked interest, worries, and even heavy protests among Russian linguists and the intelligentsia. Instead of observing the process and analysing it objectively, emotional expressions dominated. The overall situation was described as a 'crisis' of the contemporary Russian language. ${ }^{2}$ Other expressions used in this discussion are 'linguistic nihilism' and 'linguistic utilitarianism', which lead to 'semantic primitivism' and the use of brutal and indecent lexicon (Vanhala-Aniszewski 2010, Judina 2010). ${ }^{3}$

The new language usage has provoked anger in two respects: with regard to the overuse of foreign loanwords and brutal language. The Russian language has always been relatively open to foreign influences. Peter the Great brought from his journeys to Europe not only shipbuilding skills, but also dozens of new words. A century later Alexander Pushkin, the founder of the modern Russian literary language, did not hesitate to use foreign words and expressions, often of French origin. A wave of new concepts and Latin-based words was seen in the early years of the Soviet regime. However, researchers (e.g. Kostomarov 1999, Ryazanova-Clarke, Wade 1999) are right in arguing that the collapse of the Soviet Union and the economic and mental opening of Russian society triggered a true tsunami of foreign, primarily English loanwords. Most of them came with new phenomena and concepts, like monitoring, promoushn, autsorsing, klaster, klip, ekstrim. However, in many cases a new word just ousted an old and stale one filled with Soviet associations: sendvich, otel', praivesi, kreativ etc. Some of the new words are quickly adapted due to the word formation capacities of Russian: for example, the word piar (PR), generated a dozen or so derivatives (pere-/ ot-/ s-/ pro-/ zapiarit', piarshchik, etc. (see discussion about stages of integration of English lexemes into Russian in Yelenevskaya 2008: 110-115).

When discussing the massive influx of loanwords, people do not usually realize that such a process is not dangerous for the vitality of a language. Sometimes the contrary is true: an

\footnotetext{
${ }^{1}$ In this context Mechkovskaja (2006: 131, 135) uses a fairly demonstrative lexicon. She speaks of 'linguistic apartheid', which preceded the democratization process of languages, and of the dead ends of 'linguistic elitism' that lasted for centuries. See also Majdanova 2000.

${ }^{2}$ As shown by Mustajoki, Protassova (2012), the Russians like emotional language in describing contemporary social phenomena.

${ }^{3}$ Ryazanova-Clarke (2006) differentiates two levels in the 'metalinguistic discourse': one is 'state discourse', the other 'popular discourse', the latter including mass media.
} 
excessively puristic attitude to loanwords may endanger language development. The main source of loanwords, English, is a case in point. More than half of its vocabulary is foreign-based but it has not stopped it from evolving into the most spoken language in human history.

From the linguistic point of view, a more important phenomenon is the expansion of a word derivation model of compound nouns with an indeclinable first component. This used to be very rare (press-konferentsija, seks-bomba), but is now very productive: internet-kafe, master-klass, kontr-kultura, art-proiekt, etc. Some favorite initial components have emerged, including eks- (ekszhena 'wife', eks-muzh 'husband', eks-glava 'director', or even eks-privychka 'habit') and psevdo(psedvogosudarstvo 'government', psevdolekarstvo 'medicine', psevdonauchnyi 'scientific', psevdoiskusstvo 'art').

The two most recent presidents of Russia have both played a role in the expansion of brutal and colloquial lexicon. Putin is famous for peppering his speech with words originating in the prison argot. The best known of these is the phrase mochit' $v$ sortire terroristov ('to waste terrorists in the outhouse'), which he launched before becoming president (Camu 2006; more in Kostomarov 2006: 237-238). Medvedev prefers youth slang and colloquial words. He opened his speech at the University of Helsinki on 20 April 2009 by saying 'Dorogie kollegi! Mne ochen' priiatno vystupit' $v$ etom moshchnom zale" ('Dear Colleagues, it is a great pleasure for me to give a speech in this nice [powerful] hall'). Such an expression could be expected in the speech of youngsters, but not in a presidential address. The adjective moshchnyi as such is a literary word, but in this context it is used in a surprising way. As a matter of fact, Medvedev also used it in the expressions moshchnoe razvitie (development) and moshchnaia ekspertiza. To take another example of Medvedev's style: when asked about Russia's admission to the WTO, he explained the situation by saying that Russia stood in the predbannik ('dressing room of a sauna') — again a word which is not customarily used in an official context (Mustajoki 2009).

Although intelligentsia are worried about recent developments in Russian, they like to test the boundaries of the linguistic norm by including elements of non-normative language in their own speech (Mihajlova 2014). They often signal consciousness of these 'defects' by commenting on their usage expressing metalinguistic reservations and explanations (cf. Mustajoki, Vepreva 2006; Vepreva 2014): "as they say nowadays", "pardon me for the fashionable word", "I hate this new expression", "speaking in simple language", "to put it in a modern way". In other words, while people are worried about what they consider inferior language, they are at the same time distributing it. In his famous book "The Russian Language on the Brink of a Nervous Breakdown", Krongauz (2009: 215) concludes that the language is not in panic or suffering-but its users are.

\section{The official norm of Russian}

Although the Soviet Union was a strictly centralized state and although language issues were in focus in various ways during that era, no state-driven normalization processes affected the Russian language. The task of determining the official norm was outsourced to representatives of the academic community (especially to linguists working in the Soviet Academy of Sciences), who in their turn tried to listen to the opinions of intelligentsia. This was quite a reliable way to maintain a fairly stable official norm, because these people were proud of their command of good literary Russian and wanted to preserve it. In Russia, like in many other hierarchical societies, language has always been the main distinguishing feature between elites and lower social classes.

In the 1990s, the need for a legislative positioning of Russian became apparent. One reason for this was a change in the status of Russian. In Soviet times, Russian was a natural tool for crossethnic communication throughout the country. In the new state, the language retained a similar role, but the overall situation changed dramatically. In the new independent countries Russian lost its strong position, and voices for diminishing its role in some parts of Russia became audible. Another stimulus for legislative action came in the form of strong anti-normative, "democratic" trends in language use, as mentioned above. 
Serious debates preceded legislative actions, both in the media and in the Duma ${ }^{1}$. Several versions of the Language Acts were discussed. In the 2005 law, the position of Russian as the state (gosudarstvennyi) language was fixed. In addition, more than 30 other languages were granted the status of an official language in a particular region. In terms of language norms, two clauses of the acts are interesting. One states that the Government of the Russian Federation establishes the norms of the contemporary Russian literary language, and the rules of orthography and punctuation. The other relevant clause is reminiscent of the French puristic tradition in language issues by stating that it is not permissible to use foreign words that have analogy in Russian. This point provoked a multitude of cynical commentaries because in the text of the law the loanword 'analog' could have been replaced by a native Russian equivalent.

The first regulative action was taken by the Government on 1 September 2009. Four prescriptive dictionaries were accepted as models of normative language. More interestingly, the decree gave the green light to some spelling and pronunciation variants, which had previously been frequently used but were considered non-standard according to authoritative dictionaries. As a result, both jógurt and jogúrt, dogovór 'agreement' and dógovor are now accepted as correct, and one can use the word kofe 'coffee' as a neuter noun besides the traditional masculine version based on the old spelling kofej.

\section{Russian outside Russia}

The Russian spoken by people living outside Russia adds an interesting perspective to the discussion concerning a/the official norm of the language. The number of speakers belonging to this category is larger than that of native speakers living in Russia. ${ }^{2}$ One can ask to what extent the kind of Russian used in Kazakhstan, Latvia, or the USA differs from Moscow Russian. Further: are the differences sufficient to make us distinguish between different varieties of Russian? ${ }^{3}$ I will try to elaborate on this question by looking at some countries for illustration.

Belarus is the only former Soviet Republic where Russian is one of the two official languages. The status of the 'titular' language, Belarusian, is much weaker than that of Ukrainian in Ukraine. The number of people having Belarusian as their mother tongue is lower among youngsters than among the elderly. A striking phenomenon is the existence of a mixed Belarusian-Russian language called 'trasianka', which is the mother tongue of a third of the population. The great majority of the citizens of Belarus use Russian much more than Belarusian in their everyday lives, and the number of such people is increasing (Woolhiser 2014). The circumstances are ideal for the emergence of a national variety of Russian. Woolhiser interviewed Belarusians and asked them about the scale of differences between Belarusian-Russian and Russian-Russian. A layman compares the situation to that between "English in England and the USA". Many of the interviewees list words of BelarusianRussian differing from those in Russian-Russian. Differences mainly concern words used in everyday life: bul'ba 'potatoes', groshi 'money', zhonka 'wife', shyl'da 'sign' (in Russian-Russian: kartoshka, den'gi, zhena, vyveska) (Norman 2013).

Kazakhstan is another country where Russian has a strong position. Here the Kazakh language is the 'state language' and Russian is an 'official language'. In Kazakhstan, linguists have played an active role in the development of both Kazakh and Russian (Suleimenova, Smagulova 2005). This has helped the country to pursue a relatively liberal and feasible language policy. The

\footnotetext{
${ }^{1}$ The debate on the new language law has been described in several papers. For an overview see Judina 2010: 26-55. One of the most critical comments has been made by Golev (2009), who argues that a poor command of Russian by native speakers stems from school teaching where all attention is focused on 'gramotnost', i.e. the correctness of orthography and punctuation. This destroys, according to Golev, the natural language instinct of children.

${ }^{2}$ One can find different figures estimating the number of Russian-speaking people in the world; see the discussion on this issue in Mustajoki 2010: 41; Ryazanova-Clarke 2014.

${ }^{3}$ There is no obvious equivalent for the English term 'variety' in the Russian linguistic tradition. Krysin (204) speaks of 'variation' of the Russian language in non-Russian circumstances; Dorofejev (2010) uses the word 'variant'. Some use the term idiom (cf. Mustajoki 2014).
} 
use of Russian in official state-level documents forces bureaucrats to be creative in language use. Eleonora Suleimenova provides a characteristic example of the need to 'nationalize' the Russian used in local circumstances: "Osnovnymi merami $v$ dannom napravlenii stanut organizatsiia $i$ provedenie aitysov, mushaira, debatnykh turnirov $i$ konkursov shyrau i zhyrshy" (The chief measures to achieve this end is to organize and hold aitysy, mushairy, debate contests, and shurai and zhirsy competitions (Suleimenova 2011: 90). This sentence contains four words (underlined) that would be incomprehensible to a native speaker from Russia. From a traditionalist point of view, it could be regarded as incorrect or simply baffling, but in fact, the sentence is a quote from an official document. ${ }^{1}$

Let us turn to another country, Latvia, where there is a large population of Russian-speaking people (27\%) but where Russian has no official status. Berdicevskis (2014) provides several examples of lexical items differing from the standard Russian language. He explains this phenomenon by the absence of efforts to normalize the language variety, which leaves more space for innovative and individual language use. This may be true, but on the other hand, a similar desire for new words is also found on a large scale in Russian Russian. Describing characteristics of 'regional Russian speech', Zharkova (2000) discusses reasons for the use of Lithuanian words in Russian speech. ${ }^{2}$ Apart from obvious cases of local concepts (referred to as regionalisms), she takes into account speakers' cognitive efforts: if a bilingual person frequently uses a certain word in one language, he/she easily transfers it to another language as a way of reducing mental effort. A condition for such code-mixing is that such mannerisms are accepted by the speech community.

The above cases examined Russian outside Russia. Recently, increased attention has also been paid to differences in the Russian language as spoken in various Russian cities. Here we encounter a similar phenomenon: regionalisms, lexical items used only in a particular region, are frequent. As pointed out by Belikov (2009), such deviations from the standard language also occur in texts of the highest possible status, including official documents and legislation. This is an important observation because previous studies have concentrated on oral vernacular talk. ${ }^{3}$

So far we have considered lexical items. This reflects the content of studies on regional or national varieties (variants) of Russian. Interestingly, differences at other levels of the Russian language come both from various parts of Russia and from other countries. Pussinen (2010) reports on the state of Russian as used in a village in the Mordovia Republic, where the Finno-Ugric languages of Moksha and Erzya are widely spoken. She has found deviations from standard Russian in phonetics, intonation, morphology, word derivation, and syntax. Similar discoveries have been made by Andrews (2004) in Russian as spoken in the United States. Local features in Russian may also concern pragmatics, e.g., the way people use greetings and other contact expressions.

Striking deviations are found in 'island varieties of Russian' where Russian has been used as a native language for decades or centuries by isolated language communities. Bergelson and Kibrik (2010) describe the current state of Russian as spoken in Alaska. People living in the village of Ninilchik have preserved their language, although they have been surrounded by English-speakers since 1867. The Russian they speak differs from standard Russian not only in some surface details; substantial structural changes have also taken place, e.g., in the sound system and in grammatical gender. A well-known example of 'island Russian' is the language of the Old Believers (cf. this volume).

\footnotetext{
${ }^{1}$ A more detailed analysis of the Kazakhstanization of Russian in Kazakhstan is made by Suleimenova $2010 \mathrm{~b}$.

2 Pil'chinova (2013) provided a survey on the motivation for the use of 'ethnoregionalisms' in Buriatian Russian. The following explanations, among others, were given: I don't know the appropriate Russian word (nominative function), I try to create an amusing atmosphere (rhetorical function), it sounds more emotional (expressive function).

${ }^{3}$ Berdicevskis (2014: 227) refers, among other sources, to the Electronic Dictionary of Russian cities (lingvo.ru/goroda). A house with more than seven floors is called bashnja in Moscow, vysotka in Lipeck, and svechka in Yaroslavl, Volgograd, and in some other cities.
} 
We have presented enough concrete examples to answer the question about the status of different varieties of Russian, their way of developing, and illustrating how their norms are determined. This perspective enables us to distinguish three groups of cases. The varieties of Russian used in Belarus and Kazakhstan and to a lesser extent in some other former Soviet republics, where Russian appears in official documents, differs from Russian-Russian, especially in lexical terms. In most cases no systematic normalization measures are taken, but we see an inherent, 'natural' norm creation. Thus, innovations arise among native Russian speakers in these countries rather than being imported from Moscow; in that sense the process is democratic. This, however, does not mean that all the changes are bottom up. On the contrary, official state-level documents serve as a model for other written texts. The Russian used in the mass media and oral conversation develops for the most part independently of any regulation. This resembles the situation in Russia. A largely similar process takes place in Mordovia and other regions of Russia enjoying different degrees of autonomy.

The second group comprises countries with large numbers of Russian immigrants (USA, Germany, Finland etc.), where the language is used only in brochures and leaflets for foreigners and immigrants, but has no official status. The Russian spoken in these countries is more heavily influenced by the surrounding society and languages. In most cases, the collective norm of Russian is rather vague and one can observe diverse developments. There are two reasons for such a process. First, Russians speaking their mother tongue live in different parts of the country and do not always form close-knit communities. Second, new Russian immigrants are continually joining the community of Russian-speaking people. This brings fresh elements originating in Russia to the language of the diasporans. Competition usually takes place between an expression which is more archaic and/or has local color and the one that reflects new developments in Russian-Russian. Russian changes, in a manner similar to dialects or slang, due to a collective intuitive effort of the people using that language.

The third group, the 'Island Russian' varieties, differs from the previous ones in the cohesion of the community of users. In the case of the Old Believers, the language has preserved archaic features, while in Alaska Russian we see a strong influence of English. In both cases, the language development reflects the overall philosophy of these communities.

\section{Conclusion}

Democracy is not a clear notion with regard to language. Dialects, slangs, and languages without a literary norm develop on a 'bottom up' basis through consensus within the language community concerned. In the case of an official norm set 'from above', one can see anti-democratic elements because the elite determines how the rest of the people should use the language. On the other hand, this gives everyone an opportunity to learn the correct language and use it.

Until recently, the norms of the Russian language were established by academics not formally selected for that task. The new language law has changed the situation, and the authority to regulate the norm has been granted to the government. The first instance of government action in determining the norm took place in 2009. The decision was towards greater democracy in the sense that it authorized the use of some common variants that had been considered incorrect under the previous norm.

One can see democratization in the expansion of colloquial and slang expressions in the mass media. Similar shifts in language use have taken place in most Western countries, but in Russia the change has been quicker and more dramatic.

A topical issue from the point of view of the 'ownership' of the Russian language is the possible existence of several varieties of Russian. The question is whether and to what extent native Russian speakers living outside Russia should follow the official norm of Russian-Russian. Although people in Russia sometimes think that they have the right to determine how Russian is spoken and written in other countries, such an attitude is not tenable, as we have seen in the 
development of different Englishes. In countries where Russian has a more or less official status, a local variety of the language gradually acquires specific features. This process is not systematic or steered by anyone, but changes in usage occur in a natural way. In countries where Russian is not used in official documents, it develops even more freely on the basis of communicative needs. Among 'Island Russians', in Alaska, and among Old Believers, the collective norm of the language is clearly created and owned by these people. The language, spoken only by these relatively small communities of people, is a very important part of their self-esteem and sense of belongingness.

\section{Bibliography}

Andrews, D. (2004) Teorija prototipov v izuchenii russkogo jazyka v Amerike. In Mustajoki, A.; Protasova, E. (eds.) Russkojazychnyji chelovek v inojazychnom okruzhenii. Helsinki: University of Helsinki, 123-128.

Belikov, V.I. (2009) Leksicheskij uzus oficial'nyh dokumentov i kodificirovannaja slovarnaja norma. Social'nye varianty jazyka, VI, 65-68.

Berdicevskis, A. (2014) Predictors of pluricentricity: Lexical divergences between Latvian Russian and Russian Russian. In Ryazanova-Clarke: 225-245.

Bergelson, M.B.; Kibrik, A.A. (2010) The Ninilchil variety of Russian: linguistic heritage of Alaska. In Mustajoki et al.: 299-313.

Camu, R. (2006) 'We'll Whack Them, Even in the Outhouse': on a Phrase by V.V. Putin. Kultura, $10,3-6$.

Dewey, M. (2009) English as a lingua franca: Heightened variability and theoretical implications. In Mauranen, Ranta: 78-81.

Firth, A.; Wagner, J. (1997) On discourse, communication, and (some) fundamental concepts in SLA research. The Modern Language Journal, 81(3), 285-300.

Gal, S.; Irvine, J.T. (1995) The boundaries of languages and disciplines: How ideologies construct difference. Social Research, 62(4), 967-1001.

Gasparov, B.M. (2014) Jazyk—raznorechnoe edinstvo: pljuralizm rechevogo povedeniia kak osnova kommunikativnogo vzaimodeistvija govorjashchih. In Gasparov, Kupina: 14-41.

Gasparov, B.M.; Kupina, N.A. (eds.) (2014). Russkij iazyk v mnogorechnom sociokul'turnom prostranstve. Ekaterinburg: Ural University.

Golev, N.V. (2009) Sovremennoe rossijskoe obydennoe metajazykovoe soznanie mezhdu naukoj i shkol'nym kursom russkogo jazyka ("pravil'nost"” kak bazovyi postulat naivnoj lingvistiki). In Obydennoe metajazykovoe soznanie: ontologicheskie i gnoseologicheskie aspekty. Tomsk: Tomsk Pedagogical University, 387-389.

House, J. (2003) English as a lingua franca: A threat to multilingualism? Journal of Sociolinguistics, 7(4), 556-578.

Hülmbauer, C. (2009) 'We don't take the right way. We just take the way that we think you will understand'-The shifting relationship between correctness and effectiveness in ESL. In Mauranen, Ranta: 323-347.

Judina, N.V. (2010) Russkii jazyk v XXI veke: krizis? evoljuciia? progress? Moscow: Gnozis, 9-16.

Kachru, B.B. (1985) Standards and codification and sociolinguistic realism: The English language in the outer circle. In Quirk, R.; Widdowson, H. G.; Cantù, Y. (eds.) English in the World: Teaching and Learning the Language and Literatures. Cambridge: Cambridge University Press.

Kon'kov, V.I.; Potsar, A.M.; Smetanina, S.I. (2004) Jazyk SMI: sovremennoe sostojanie i tendencii razvitija. In Sovremennaja rech': sostojanie i funkcionirovanie. St. Petersburg: Akademija, $67-82$.

Kortmann, B.; Lunkenheimer, K. (eds.) (2013) The Electronic World Atlas of Varieties of English. Leipzig: Max Planck Institute for Evolutionary Anthropology. ewave-atlas.org

Kostomarov, V.G. (1999) Jazykovoj vkus epohi. St. Petersburg: Zlatoust. 
(2006) Nash jazyk v dejstvii. Ocherki sovremennoi stilistiki. Moscow: Gardariki.

Kristiansen, T.; Coupland, N. (eds.) (2011) Standard Languages and Language Standards in Changing Europe. Oslo: Novus.

Krongauz, M.A. (2009) Russkii jazyk na grani nervnogo sryva. Moscow: Znak.

Krysin, L.P. (2000) O nekotoryh izmenenijah v russkom jazyke XX veka. Issledovanija po slavjanskim jazykam, 5, 63-91.

Krysin, L.P. (2004) Russkoe slovo, svoe i chuzhoe. Moscow: Jazyki slavjankoj kul'tury, 404-410.

Lähteenmäki, M.; Vanhala-Aniszwski, M. (eds.) (2010) Language Ideologies in Transition Multilingualism in Russia and Finland. Frankfurt/Main: Lang.

Majdanova, L.L. (2000) Gazetno-publitsisticheskij stil': metamorfozy kommunikantov. In Kupina, N.A. (ed.) Kul'turno-rechevaia situatsiia v sovremennoi Rossii. Ekaterinburg: Ural University, 245-252.

Majorov, A.P. (ed.) (2013) Regional'nye varianty nacional'nogo jazyka. Ulan-Ude: MO Buriatii.

Mauranen, A. (2006) Signalling and preventing misunderstanding in English as lingua franca communication. International Journal of Sociology of Language, 177, 123-150.

Mauranen, A.; Ranta, E. (eds.) (2009) English as a Lingua Franca. Studies and Findings. Newcastle-upon-Tyne: Cambridge Scholars Publishing, 78-81.

Mechkovskaja, N.B. (2006) Demokratizacija jazykov: faktory, kollizii i al'ternativy. Acta Neophilologica VIII. Olsztyn: Wydawnictwo UWM.

Mihajlova. O. (2014) Poliglossija rossijaniana v leksikograficheskom predstavlenii. In Gasparov, Kupina: $68-77$.

Mustajoki, A. (2009) Venäjän kielen monet kasvot. Idäntutkimus 2, 70-74. (2010) Types of non-standard communication encounters with special reference to Russian. In Lähteenmäki, Vanhala-Aniszwski, 35-55.

(2011) Pochemu obshchenie na lingva franka udaetsia tak khorosho? In Jazyki sosedej: mosty ili bar'ery. Problemy dvuiazychnoi kommunikacii. St. Petersburg: EUvSP, 10-31. (2013) Raznovidnosti russkogo jazyka: analiz i klassifikacija. Voprosy jazykoznanija, 5, 327.

Mustajoki, A.; Protassova, E.; Vakhtin, N. (eds.) (2010) Instrumentarium of Linguistics: Sociolinguistic Approaches to Non-Standard Russian. Helsinki: University of Helsinki.

Mustajoki, A.; Vepreva, I.T. (2006) Kakoe ono, modnoe slovo: k voprosu o parametrakh iazykovoi mody. Russkij jazyk za rubezhom, 2, 45-63.

Norman, B.Y. (2013) Mozhno li govorit' o belorusskom variante russkogo iazyka. In Majorov: 7881.

Pil'chinova, M.M. (2013) Faktory prisutstvija regionalizmov v razgovornoj rechi zhitelej Burjatii. In Majorov: 81-83.

Pussinen, O. (2010). Osobennosti jazykovoii situacii i russkogo jazyka v Mordovii. In Mustajoki et al.: 106-126.

Ryazanova-Clarke, L. (2006) The crystallisation of structure: Linguistic culture in Putin's Russia. In Lunde, I.; Roesen, T. (eds.) Landslide of the norm: Language Culture in Post-Soviet Russia. Bergen: University of Bergen, 31-63. (ed.) The Russian Language outside the Nation. Edinburgh: University of Edinburgh, 1-30.

Ryazanova-Clarke, L.; Wade, T. (1999) The Russian Language Today. London: Routledge.

Shcherba, L.V. (1974/2007) Jazykovaia sistema i rechevaja dejatel'nost'. Moscow: KomKniga.

Suleimenova, E.D. (2010a) Glavnyi vektor grazhdanskoi identichnosti. In Suleimenova, E.D. (ed.) Dinamika jazykovoi situacii v Kazahstane. Almaty: Minkult Kazahstan, 48-66.

(2010b) K osmysleniju verojatnosti varianta russkogo jazyka v Kazahstane. In Mustajoki et al.: $252-265$.

(2011) Jazkovye processy i politika. Almaty: Kazak universiteti. 
Suleimenova, E.D., Smagulova, Z.S. (2005) Jazykovaia situaciia i jazykovoe planirovanie v Kazahstane. Almaty: Kazak universiteti.

Taylor, T.J. (1990) Which is to be master? The institutionalisation of authority in the science of language. In Joseph, J.E.; Taylor, T.J. (eds.) Ideologies of Language. London: Routledge, 924.

Vanhala-Aniszewski, M. (2010) Unity or diversity? The language ideology debate in Russian media texts. In Lähteenmäki, Vanhala-Aniszwski, 101-121.

Vepreva, I.T. (2014) Metajazykovoe izmerenie mnogorechija. In Gasparov, Kupina: 51-67.

Woolhiser, C. (2014) The Russian language in Belarus: language use, speaker identities and metalinguistic discourse. In Ryazanova-Clarke: 81-116.

Yelenevskaya, M. (2008) Russian: From socialist realism to reality show. In Rosenhouse, J.; Kowner, R. (eds.) Globally Speaking: Motives for Adopting English Vocabulary in Other Languages. Clevedon: Multilingual Matters, 98-120.

Zemskaja, E.A. (1987) Russkaja razgovornaia rech': lingvisticheskij analiz i problemy obuchenija. Moscow: Russkij iazyk.

(1996) Vvedenie. In Russkij iazyk konca XX stoletija. Moscow: Jazyki russkoj kul'tury, 914.

Zharkova, A. (2000). Rodnaja rech' russkih v Litve (Problemy normativnosti). In Trudy po russkoj $i$ slavjanskoi filologii. Lingvistika. Novaja seria III. Jazyk diaspory: problemy i perspektivy. Tartu: Tartu Ülikool, 47-53. 